\title{
Bacterial Protein Toxins
}

\section{P. FAlMAGne, J.E. Alouf, F.J. FEHRENBACH,} J. JELJASZEWICZ, M. THELESTAM (Eds.)

Zentralblatt für Bakteriologie und Hygiene, Supplement Vol. 15

Gustav Fischer Verlag, Stuttgart-New York 1986

398 pages, 93 figures, 64 tables

The book "Bacterial Protein Toxins" cover all aspects of the broad field of protein toxins: their structure, synthesis, secretion, genetics, factors of virulence, interaction with cell receptors and membranes, mechanisms of biological and immunological effects, etc. It contains chapters on the application of toxicology in human medicine - diagnostics, therapy, development of new vaccines, construction of toxin genes, and includes contributions by experts in many scientific disciplines, such as biophysics, biochemistry, molecular and cellular biology, genetics, immunology, microbiology and medicine.

The volume should not lack on the bookshelves of not only toxinologists but of all biologists.

J. HOFMAN 